\title{
Review
}

\section{The human rights state: Justice within and beyond sovereign nations}

\author{
Benjamin Gregg \\ University of Pennsylvania Press, Philadelphia, 2016, viii+283 pp., \\ ISBN: 978-0-8122-4805-0
}

Contemporary Political Theory (2018) 17, S90-S93. https://doi.org/10.1057/s41296017-0120-4; published online 15 June 2017

The Human Rights State is an important work of political imagination. This is a compliment to the author and an evaluation of the book's argument. In prose, both light and evocative Benjamin Gregg asks us to rethink human rights as a freestanding moral ideal to which we should aspire. Rather than seeking a foundation for rights, however tenuous and contingent, he argues that the only grounding human rights need is found in 'an intuition about justice, an interest in justice, a motivation to do justice' (p. 11). The indefinite article is important, as Gregg wants to understand human rights as social constructions that are very much still under construction, and as such open to interpretation from a multitude of moral perspectives. This multitude is held together by an intentionally vague but universal sense of justice - in all its diverse expressions - and a functional necessity to protect individuals from the power of the modern state.

Elements of this approach are familiar from recent attempts to rethink human rights as grounded on contingent practical or political foundations. Gregg's book, however, takes this familiar project in an idiosyncratic and invigorating direction, which provides both the most promising and least satisfying elements of the project. By taking the social construction of human rights seriously, Gregg clears the way for an uncompromising recognition that human rights are claims people make for themselves, from within their own context and in response to the particular injustices they face. This political and activist understanding of rights is an important conceptual move. Following from this, he makes the case that human rights and the nation state are intrinsically linked. Yet this relationship is defined by an inherent tension. Human rights entail a transfer of sovereignty from the national territorialised community to the diverse de-territorialised individual human body. Gregg talks of an imaged human rights state that exists in the collective consciousness of dedicated activists and a human rights backpack used to arm the vulnerable for political engagement. Yet, these metaphorical moves are in some

(C) 2017 Macmillan Publishers Ltd. 1470-8914 Contemporary Political Theory Vol. 17, S2, S90-S93 
measure stifled by the complacent liberal view of the politics and institutions involved in realising the human rights state.

In the first section of the book, Gregg re-conceptualises human rights. His first move is to elaborate the human rights state as an idea: it is an imagined political community called into existence by individuals; it is not, however, a universal community, as the creation of a human rights state is a response to a distinctive context of injustice. Therefore, the normative content of the human rights state is drawn from the particular political and cultural milieu that inspires its inception, even as its normative claims aspire to universality. Further, there are many human rights states, each distinctive but linked by the ambition of overcoming the exclusive sovereignty of the nation state. Most fundamentally, Gregg is suggesting that a human rights state emerges from the normative contradiction at the heart of national sovereignty, which makes the state both arbiter and creator of the law. The human rights state is an imagined community that grants individuals the authority to make their own rights claims and recognises the legitimacy of those claims. This is why Gregg suggests that a 'human rights state operates alongside a corresponding nation state' (p. 35) and 'seeks to make that recognition and self-granting acceptable within the terms of a modified nation state sovereignty'. (p. 36). There are many human rights states, perhaps many corresponding with one nation state. But this diversity serves the purpose of reforming existing nation states rather than creating new ones. Here we have the first example of Gregg's imaginative and acquiescent impulses coming into tension.

In the remainder of the first section, Gregg expands upon the creative political potential of the human rights state and its deontic power to make rights claims that seek to transform the nation state. In Chapter 2, he offers the idea of a human rights backpack as a way of metaphorically de-territorialising human rights. This entails thinking of the source of our rights as coming not from our membership in a nation state but rather from human action that performs these new rights claims, expressing the non-formalised power of individuals working in concert. The backpack then represents the transfer of political agency from the national sovereign community to the mobile individual acting in concert but resolutely autonomous. The content of the backpack is the performance, 'the donning of the backpack, of displaying the backpack, of carrying human rights in the backpack, or sharing the backpack's human rights with others' (p. 53). This performative reading of human rights is linked to the human body in Chapter 3, in which Gregg challenges the inside/outside border logic of national sovereignty. He considers the figure of the modern slave, drawing out how individuals in this state find no value in border logic as they are denied membership, thus existing always outside the community of rights and laws, while also experiencing the protection of sovereignty as a further threat to themselves. Drawing on this analysis Gregg argues that we should understand the human body as having the power to border the world, to draw the distinctions between inside and outside. 'I propose endogenizing

(c) 2017 Macmillan Publishers Ltd. 1470-8914 Contemporary Political Theory Vol. 17, S2, S90-S93 S91 
the bordering function by transferring it from the nation state to the individual members of a human rights state. Then border jurisdiction ceases to be a matter of where an individual resides and becomes a matter of what an individual has been assigned'. (p. 67) Rights, then, are not present where the individual is recognised but rather when individuals have worked to assign and recognise their own rights.

The first three chapters of Gregg's book offer a promising reconceptualisation of human rights, with a breadth that is evocative but without sufficient depth to be wholly convincing. I have focused on the arguments in the first section because I think they are filled with promise, as they break down divides between critical and apologetic accounts of human rights, and between theory and practice. Yet, the rest of the book is less inspiring as it tries to fill out the conceptual sketch at the start. In section two, Gregg wrestles with the practicalities of how the human rights state can engage in effective political action. He considers how the human rights state might be realised through university education in the US (Chapter 4), through informal political education in Eastern Europe (Chapter 5) and through advances in digital communication technologies (Chapter 6). Each chapter offers insights into how this work might be done, but the imagination that sets the early sections of the book apart wanes.

In particular, Gregg's focus on political action as persuasion rather than coercion seems naive in our contemporary moment. I am not suggesting that human rights are best served by coercion or violence, but rather that anyone hoping that human rights might challenge the violent and coercive power of the nation state needs to consider political action more carefully. Insufficient attention is given to the material prerequisites to engage in the kind of sustained activism Gregg advocates. Further, he does not seem to appreciate the extent to which building the effective power of the human rights state involves taking power from the actually existing nation state, including the individuals and communities that benefit from the existing order. It would have been more useful for Gregg to consider practical cases like the Black Lives Matter movement in the US or the EU migration crisis, as they would have done more to develop the political element of the argument and allowed for a more focused consideration of the extent to which the nation state is amenable to reform.

In the final section of the book, Gregg turns to the challenges to the human rights state, and his assessment is both too sanguine and too modest. He is at his most, convincing and arguing, against using armed intervention as a tool of human rights promotion, rightly suggesting it needs to be an exceptional tactic of last resort, as all it can hope to accomplish is putting an end to the killing of innocent civilians. His view that patriotism can be rendered in more cosmopolitan terms, while admirably aware of the challenges, reads as optimistic in the face of the recent rise of virulent populist politics, for example. And finally, in defending the rule of law rather than democracy as essential to the human rights state, Gregg takes a step backward. While a hesitance to articulate a universal institutional form is 
understandable, he undercuts his own argument. The human rights state he imagines is expressly a democratic vision, as it seeks to carry forward the power of individuals to make their political and social lives for themselves in concert with others. The rule of law may be an important tool to realising this vision but its moral core is a democratic impulse of inclusion. The most compelling moments of the book take up that democratic impulse: it is an unhappy capitulation that they are not followed through. Nonetheless, Gregg has given us a lively and important book, filled with potential and frustration, but steadfastly trying to do some good in our troubled times, for which it is both a deeply democratic and commendable book.

Joe Hoover

Queen Mary University of London, London E1 4NS, UK j.hoover@qmul.ac.uk

Centre for Global Cooperation Research, 47059 Duisburg, Germany hoover@gcr21.uniue.de 